\title{
Studies on Preparation and UHPLC Analysis of the Usnea Barbata (L) F.H.Wigg Dry acetone extract
}

\begin{abstract}
VIOLETA POPOVICl ${ }^{1}$, LAURA BUCUR ${ }^{2 *}$, TEODOR COSTACHE ${ }^{3}$, DANIELA GHERGHEL ${ }^{4}$, GABRIELA VOCHITA ${ }^{4}$, COSMIN TEODOR MIHAI ${ }^{4,5}$, PINCU ROTINBERG ${ }^{4}$, VERGINICA SCHRODER ${ }^{2}$, FLORIN CIPRIAN BADEA ${ }^{1}$, VICTORIA BADEA ${ }^{1}$

${ }^{1}$ Ovidius University of Constanta, Faculty of Dental Medicine, 7 Ilarie Voronca Str., 900409, Constanta, Romania

${ }^{2}$ Ovidius University of Constanta, Faculty of Pharmacy, 6 Capitan Al. Serbanescu Str., Constanta, Romania

${ }^{3}$ SCIENT Research Centre for Instrumental Analysis, 1 Petre Ispirescu Str., Tancabesti, Romania

${ }^{4}$ Institute of Biological Research lasi, branch of NIRDBS, 47 Lascar Catargi Str., 700107 Iasi, Romania

${ }^{5} \mathrm{Advanced}$ Centre for Research and Development in Experimental Medicine (CEMEX), Grigore T. Popa University of Medicine and Pharmacy lasi, 9-13Mihail Kogalniceanu Str., 700259, Iasi, Romania
\end{abstract}

\begin{abstract}
In the category of medicinal plants with remarkable therapeutic properties, lichens are also included. An important representative of this group is the Usnea Adans. genus, with over 650 species spread throughout the globe. Representative species of this genus were also found in Romania, so the studies were conducted on Usnea barbata (L.) F.H.Wigg., harvested from the Calimani Mountains, Suceava County. The objectives of this research are: obtaining the dry extract of the Usneae lichen followed by the identification and determination of the usnic acid content by ultra-high performance liquid chromatography (UHPLC) method. Usnic acid content determined in dry extract of Usnea barbata (L.) F.H.Wigg. was significant, of $16.53 \pm$ $6.53 \%$ (mean $\pm R S D$ ), which supports the continuation of the research with the evaluation of biological effects (antibacterial, antioxidant and antitumoral).
\end{abstract}

Keywords: Usnea barbata (L.) F.H.Wigg dry extract, usnic acid, UHPLC

In recent years, there has been an increasing tendency to supplement the action of synthetic drugs, whose therapeutic benefits are doubled by multiple adverse effects, with natural remedies. Many plants have antioxidant properties, especially due to the content of polyphenols; these constituents have an important role in the normal growth and the development of plants, as well as in the development of the oxidative stress defense abilities $[3,4,8,13]$. Among the plants with remarkable therapeutic properties, there are also the lichens $[7,12$, 17]. Structurally, the lichens represent a symbiosis between a fungus (mycobiont) and a green alga or a cyanobacteria (photobiont); the resulting thallus is completely different from the structure of each component. The special dual structure of the lichens and the specific conditions in which they live, determine the synthesis of many metabolic products, which provide them with optimal protection against disruptive, physical and biological factors [1, 12, $16,17]$. The metabolites produced by lichens are divided into two major categories: primary and secondary metabolites. The primary metabolites are produced by intracellular metabolism (proteins, aminoacids, polysaccharides); the secondary metabolites are the majority of organic compounds that characterize the lichen phytochemistry,-being synthesized exclusively by mycobiont (polyphenols, terpenes, dibenzofurans, depsides, carotenoids, steroids) [1, 12, 17, 19]. The secondary metabolites are extracellular and they are stored in the crystal form on the surface of the hyphae of mycobiont; more than 800 such compounds have now been isolated. They have a very low solubility in water, and their extraction is realized with organic solvents. Usually, the secondary metabolites content may vary between $0.1-10 \%$, but, sometimes, it can reach up to $30 \%$, relative to the dry vegetable mass $[12,16]$.

An important representative of this group is the Usnea Adans. genus, with over 650 species spread throughout the globe. The scientific literature shows that the lichens of the genus Usnea Adans. are used in traditional medicine for thousands of years to treat various diseases [12, 14, 15]. For all lichens of this genus, the common secondary metabolite is the usnic acid, an organic compound with dibenzofuranic structure $[10,16,17,19]$. Representatives of the Usnea Adans. genus are found in Romania, so that the present study was conducted on Usnea barbata (L.) F.H.Wigg., harvested from mountain areas (Calimani Mountains); this region is characterized by a low degree of pollution.

\section{Experimental part \\ Material}

Usneae lichen is Usnea barbata (L.) F.H.Wigg dried thalli; this lichen was identified based on the anatomical characters described in the literature $[8,12]$. The freshly harvested lichen thalli were cleaned from impurities and dried at constant temperature below $25^{\circ} \mathrm{C}$ in an airy room, sheltered from the sun. The dry thalli (Usneae lichen) have been properly preserved under the above-mentioned conditions. To obtain the dry extract, the Usneae lichen was milled as a powder and held for $8 \mathrm{~h}$ with acetone in a Soxhlet continuous reflux system at $70^{\circ} \mathrm{C}$; for evaporating the solvent, it was used the rotary evaporator TURBOVAP 500 Caliper $[2,11,20]$. The dry acetone extract was transferred to a sealed-glass bottle and stored in the freezer at below $-20^{\circ} \mathrm{C}$ until processing [17].

\section{Ultra-High Performance Liquid Chromatography (UHPLC) method}

Identification and determination of usnic acid content was performed by the UHPLC method [9]. This method had the following features: UHPLC Perkin-Elmer FLEXAR, binary pump, PDA plus detector, thermostatic compartment for the column, degassing system,

\footnotetext{
*email: adrianabucur@yahoo.com
} 


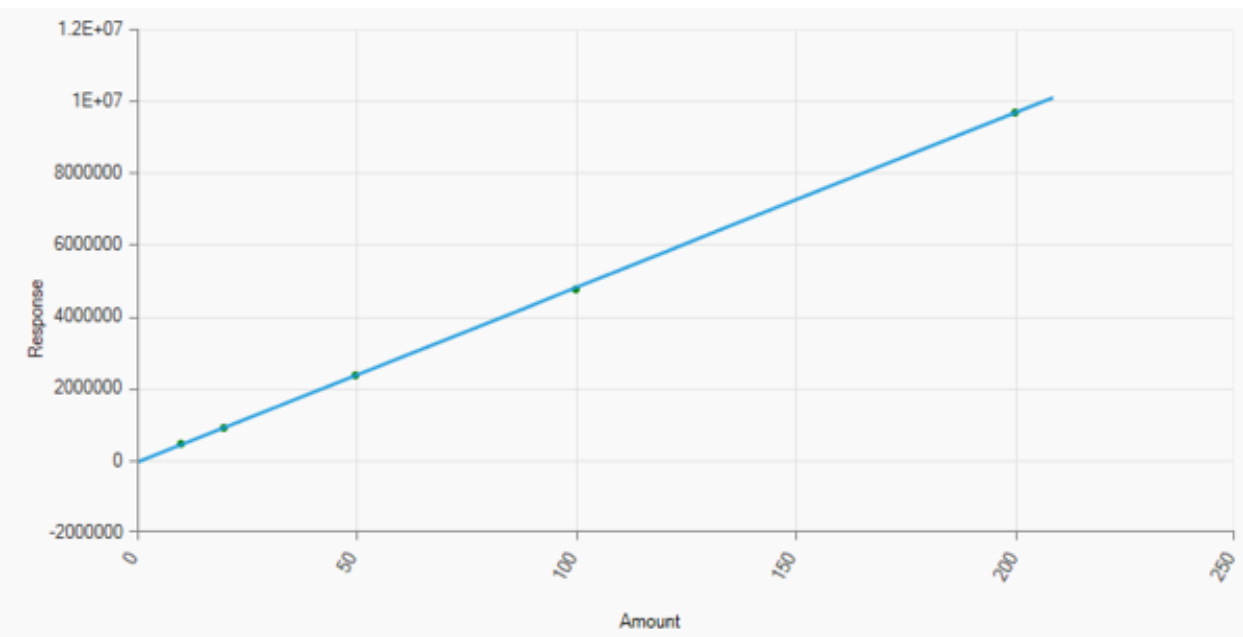

Fig. 1. Calibration curve of usnic acid

data $05: 282: 5: 395: 5: 1$

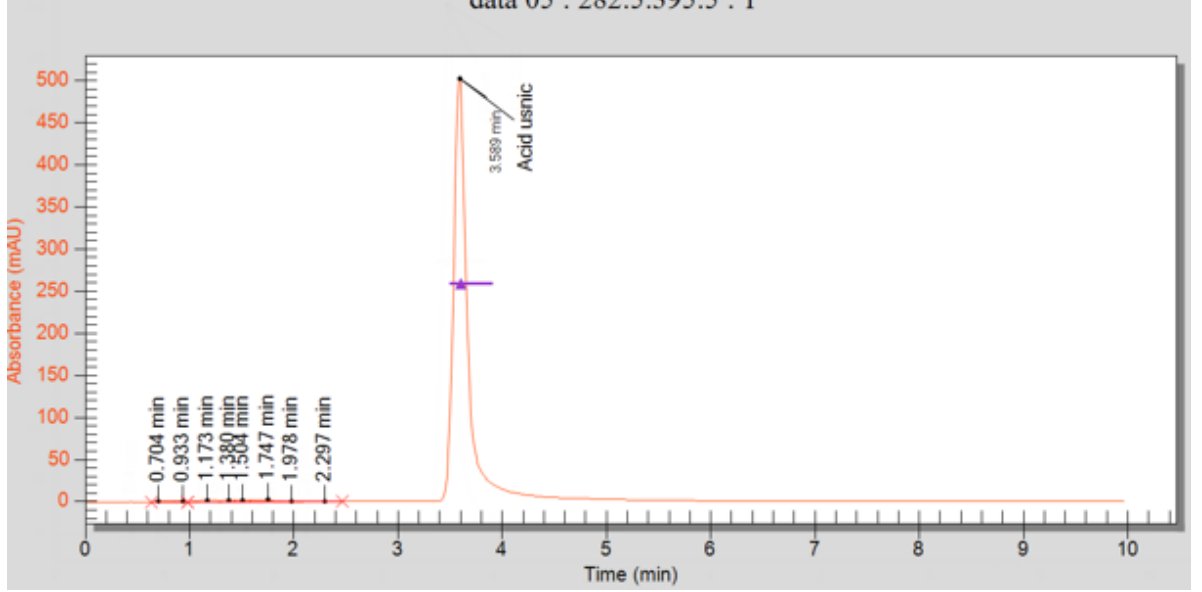

Fig. 2. Chromatogram of usnic acid at the concentration of $100 \mu \mathrm{g} / \mathrm{mL}$

autosampler. Working conditions consisted of: $\mathrm{C} 18$ column, $150 \mathrm{~mm} / 4.6 \mathrm{~mm} ; 5$ um (Perkin-Elmer); mobile phase in an isocratic system: methanol: water: glacial acetic acid = 80: 15: 5; detection: UV $=282 \mathrm{~nm}$; flow = $1.5 \mathrm{~mL} / \mathrm{min}$; temperature in the column compartment = $25^{\circ} \mathrm{C}$; injection volume $=20 \mu \mathrm{L}$; analysis time: $6 \mathrm{~min}$. Sample: the dry Usnea barbata extract was solubilized in DMSO in $0.2 \%$ concentration, diluted 1 to 10,1 to 20 and 1 to 50. Reference substance: usnic acid in DMSO at concentrations of $10,20,50,100,200 \mu \mathrm{g} / \mathrm{mL}$, with which the calibration curve was drawn $(y=4.84629 \mathrm{E}+04 \mathrm{x}$ 4.01679E + 04; $\left.r^{2}: 0.999877\right)$, shown in fig. 1 .

The following parameters were evaluated for validation of the method: specificity, accuracy, repeatability, precision, limit of detection (LOD) and limit of quantification (LOQ) [9]. The linearity of the method was verified by the method of least squares, on the $10 \mu \mathrm{g} / \mathrm{mL}-200 \mu \mathrm{g} / \mathrm{mL}$ range, for a value of $R^{2}>0.99$.

Identification and quantification of the usnic acid were based on the reference substance for which the retention time was determined at RT $=3.64 \pm 0.07$ min (fig. 2).

\section{Results and discussions}

Obtaining of Usneae extract

From $100 \mathrm{~g}$ of Usneae lichen, $7.97 \mathrm{~g}$ of dry extract (Usneae extract) was obtained (fig. 3).

The dry extracthas a greenish-brown coloration, a strong acetone odour and a spicy taste. It was stored in a freezer, at a temperature below $-20^{\circ} \mathrm{C}$ until it was used.

\section{UHPLC analysis}

The sample to be analysed has a peak at retention time $\mathrm{RT}=3.70 \mathrm{~min}$; it was identified based on the reference substances, as usnic acid. The method calibration is linear with $r^{2}=0.999877$; the accuracy is $2.26 \%$; the method precision, calculated as repeatability at the concentration

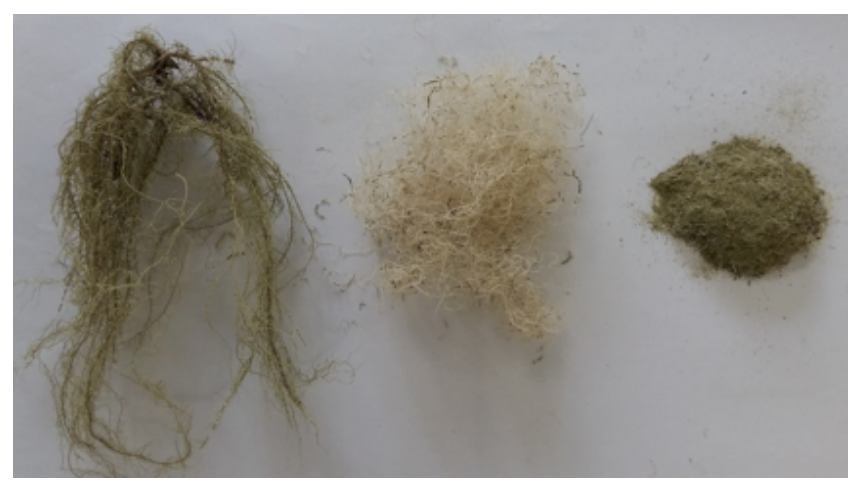

Fig. 3. Usneae lichen whole and powder

$100 \mu \mathrm{g} / \mathrm{mL}$, is 1.16\%; the limit of quantification (LOQ) was found to be $0.20 \mu \mathrm{g} / \mathrm{mL}$ with a signal-to-noise ratio = $14: 1$ and the limit of detection (LOD) was estimated at $0.04 \mu \mathrm{g} / \mathrm{mL}[9,22]$.

Determination of the Usneae extract composition was performed on three dilutions of $0.2 \%$ extract in DMSO: 1 to 10, 1 to 20 and 1 to 50 (fig. 4).

The usnic acid content determined in Usnea barbata dry extract, by UHPLC method, was $16.53 \pm 6.53 \%$ (mean \pm RSD). In the chromatograms of diluted 1:10, 1:20, 1:50 solutions, the presence of other, yet unidentified, organic compounds, that may contribute to the therapeutic potential of the Usneae extract, was also observed.

In the accessed scientific literature, the obtaining of dry lichen extracts is a common method used for: chromatographic determinations of chemical constituents, isolation of active compounds and determination of biological actions $[8,12,16]$. The provided methods are similar to those used in this study. The amount of $7.97 \mathrm{~g}$ dry extract obtained from $100 \mathrm{~g}$ Usneae lichen (harvested from Calimani Mountains) is proportional to the same quantity mentioned in the literature: from $400 \mathrm{~g}$ Usnea flexuosa 


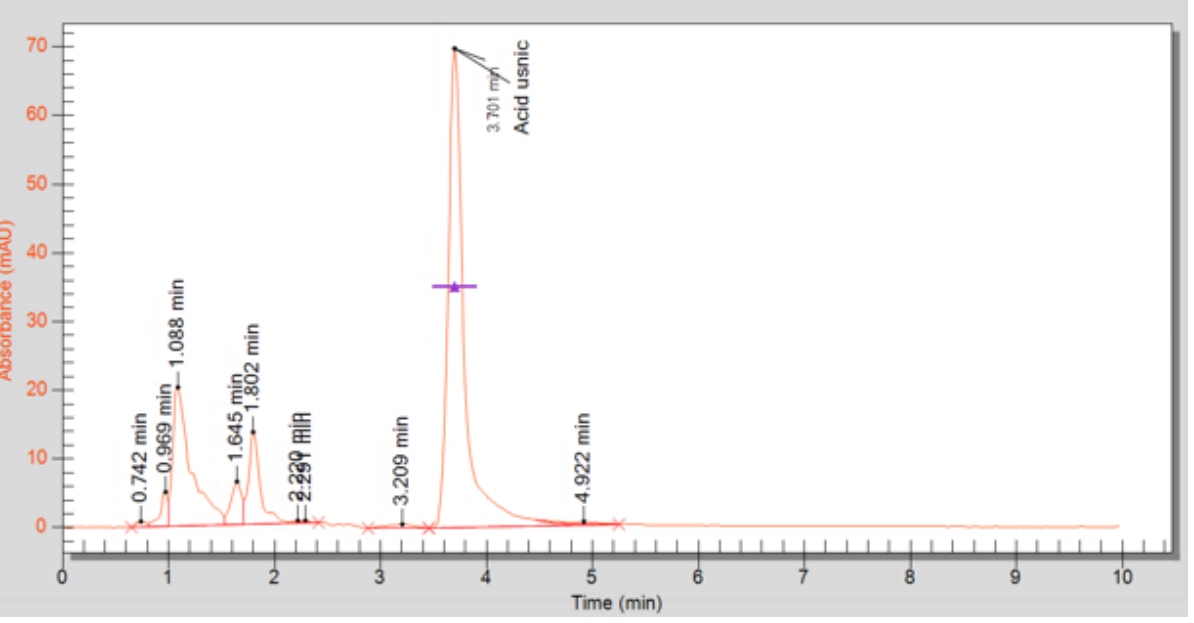

Fig. 4. Chromatogram of Usneae extract $0.2 \%$ in DMSO dilution $1 / 20$

Tayl., Maulidiyah et al. there were obtained $28.79 \mathrm{~g}$ dry extract, by the same method [11].

Determination of the usnic acid content by chromatographic methods was performed on lichen extracts obtained using different solvents, by various methods: maceration, successive extractions in different solvents at the Soxhlet apparatus, supercritical $\mathrm{CO}_{2}$ extraction [5, 6, 21].

The usnic acid content is correlated with the following parameters: solubility of this compound in the solventused for extraction, the temperature at which the extractive process was realised, the time assigned to the operation and the quantitative ratio of the Usneae lichen to the solvent.

Zugic et al. (2016) determined the usnic acid content by HPLC in Usnea barbata extracts using supercritical $\mathrm{CO}_{2}$ and ethyl-ether, as solvents. The values - of the usnic acid content were higher: $81.41 \%$ in the supercritical fluid $\mathrm{CO}_{2}$ extract and $67.09 \%$ in the ethyl-ether extract obtained by extraction at the Soxhlet, compared with $16.53 \%$ in the dry acetone extract of this present study [21].

In the cold macerated acetone extract of Usnea barbata harvested from Anatolia (Turkey), Cansaran et al. quantified $2.16 \%$ usnic acid; a value very close to the one mentioned above, was also found in the acetone extract obtained by cold maceration of Usnea barbata from the Calimani Mountains $(2.12 \%)[5,6,15]$.

In the present study, the research has focused on the quantification of usnic acid in Usnea barbata dry acetone extract. Compared to cold maceration in acetone, where the amount of usnic acid was $2.12 \%$, the solubility of usnic acid significantly increased in reflux condition, $8 \mathrm{~h}$ at $70^{\circ} \mathrm{C}$, obtaining $16.5 \pm 6.53 \%$ (mean \pm RSD) [15].

Since acetone is not a suitable solventfor HPLC analysis, because it strongly absorbs and deforms the peak of the solution for analysis, in this study we used DMSO as solvent for the solubilisation of dry extract. DMSO was used, as well, in other research found in literature [14]. The choice is justified by the intention to continue the analysis on dry extract with biological research where DMSO is the recommended solvent $[14,18]$.

\section{Conclusions}

The UHPLC analysis of Usneae lichen dry acetone extract reveals an 8-fold higher content of usnic acid than cold acetone macerated extract.

The presence of a high amount of usnic acid justifies further research with biological studies to evaluate the antimicrobial, antioxidant and antitumoral activities of Usneae extract.
This study provides an importantbasis for further research in order to identify the other relevant organic compounds, followed by the exploration of their therapeutic actions.

Acknowledges: We mention that this study was done in collaboration with the SCIENT Research Centre for Instrumental Analysis.

\section{References}

1.ADESALU, T., AGADAGBA, T., Ife J ournal of Science, 18, 2016, no. 2., p. 427

2.AYDIN, S., KINALIOGLU A., SOKMEN B., Bangladesh J. Bot., 47, 2018, no.3, p. 429

3.BUCUR, L., VLASE, L., ISTUDOR, V., Farmacia, 57, 2009, no.6, p. 736 4.BUCUR L., TARALUNGA, G., SCHRODER V., Farmacia, 64, 2016; no. 2, p. 198

5.CANSARAN, D., ARAS, S., ATAKOL, 0., JABS, 2, 2008, no.3, p. 41

6.CANSARAN, D., KAHYA, D., YURDAKULOL, E., ATAKOL, O., Naturforsch., 61, 2006; p. 773

7.FERNANDEZ-MORIANO, C., GONZALES-BURGOS, E., DIVAKAR P., Hindawi Publishing Corporation Evidence-Based Complementary and Alternative Medicine, 1, 2016, p. 1

8.HANCIANU, M., APROTOSOAIE, C., MIRON, A., Plante medicinale de la A la Z, 2, Polirom, 2014, p. 1261

9.KAYNAK M.S., CELEBIER M., SAHIN S., ALTINOZ S., Rev. Chim. (Bucharest), 64, 2013, no. 1, p. 27

10.LUCARINI, R., TOZATTI, M., African Journal of Biotechnology 11, 2012 no 20, p. 4636

11.MAULIDIYAH, A., HERRY C., WAHYUDI P.S., Indo. J. Chem., 11, 2011, no. 3, p. 290

12.MERILLON J.M., RAMAVAT K.(eds), Co-Evolution of Secondary Metabolites, 1, Springer Nature Switzerland AG, 2018, p. 1

13.MIHAI, S., DUMITRESCU, D., RADUCANU, M.A, STOICESCU, I., BADEA, V., Rev. Chim. (Bucharest), 70, 2019, no. 1, p. 23

14.ORAN, S., SAHIN, S., SAHINTURK, P., IJ PR, 15, 2016, no. 2, p. 527 15.POPOVICI, V., BUCUR, L., POPESCU, A., CARAIANE, A., BADEA, V., Farmacia, 66, 2018, no. 2, p. 337

16.PRATEEKSHA, G., PALIYA, B.S., BAJ PAI, R., RSC Adv., 6, 2016, p. 21672

17.RANKOVIÆE, B., Lichen Secondary Metabolites Bioactive Properties and Pharmaceutical Potential, 1, Springer International Publishing, 2015, p. 10

18.RANKOVIC, B., KOSANIC, M., STANOJ KOVIC, T., Int. J. Mol. Sci. 13, 2012, p. 14707

19.SANTIAGO, K., SANGVICHIEN, E., BOONPRAGOB, K., Mycosphere, 4, 2013; no.2, p. 267

20.TAS, I., YILDIRIM, A., COBANOGLU, G., European Journal of Biomedical and Pharmaceutical Sciences, 4, 2017, no. 04, p. 13 21. ZUGIC A., JEREMIC I., ISAKOVIC A., PLOS ONE, 11, 2016, no.1, p. 1

22.*** EMEA, ICH Topic Q 2 (R1)/ CPMP/ICH/381/95, 1995, p.13 